Volume 1, Issue 2, October 2020, p. 39 - 43

P-ISSN 2745-6498, E-ISSN 2745-8008

\title{
Hasil Pemeriksaan Laboratorik pada Ibu Preeklampsia dengan Risiko Terjadinya Severe Maternal Morbidity
}

\author{
Iis Tri Utami ${ }^{\left.{ }^{*}\right)}$, Mohammad Hakimi ${ }^{2}$ \\ ${ }^{\left.1^{*}\right)}$ Universitas Aisyiyah Yogyakarta \\ ${ }^{2}$ Universitas Gajah Mada
}

\section{ARTICLE INFO}

Keyword:

Severe Preeclampsia

Eclampsia

HELLP Syndrome

Severe Maternal Morbidity

\section{*) corresponding author}

Universitas Aisyiyah Yogyakarta

Jl.Padat karya Perum Indo griya

Pangkalpinang Kepulauan Bangka Belitung, 082284456389

Email:

jannatunnaim892@gmail.com

\begin{abstract}
A B S T R A C T
Morbidity and mortality in preeclampsia is still very high. In order to reduce maternal morbidity and mortality, serious efforts are needed. Those efforts are prevention, early treatment, appropriate therapeutic management and laboratory assessment. That examination can predict the risk of preeclampsia in pregnant women to severe maternal morbidity. In this study, the researcher only examined laboratory assessment results, that are platelet sexamination, creatineand SGOT /AST. The research hypothesis of Severe Maternal Morbidity was found more in preeclamptic mothers whose laboratory results were abnormal compared to preeclamptic mothers whose laboratory results were normal. The sample of the study were all preeclampsia mothers from January 1st, 2014 to December 31st, 2017. The abnormal laboratory examination results for preeclampsia women with the occurrence of severe maternal morbidity obtained p value 0,001 and OR 4,384 (95 percent $\mathrm{CI}$ : 2,053 - 9,361). This can be concluded that mothers with abnormal laboratory results are at risk of experiencing severe maternal morbidity 4,384 times compared to mothers with normal laboratory results. The conclusions of laboratory examinatio results. Have a significant relationship with the occurrence of severe maternal morbidity
\end{abstract}

This open access article is under the CC-BY-SA license.

\section{Kata kunci:}

Preeklampsia Berat Eklampsia

HELLP Syndrome

Severe Maternal

\section{A B STRAK}

Morbiditas dan mortalitas pada preeklampsia masih sangat tinggi,untuk menurunkan angka morbiditas dan mortalitas maternal diperlukan upaya sungguh-sungguh yaitu dengan melakukan usaha pencegahan, penanganan dini, manajemen terapi yang tepat dan penilaian laboratorik sehingga dapat memprediksi risiko perkembangan preeklampsia pada ibu hamil menjadi severe maternal morbidity. Dalam penelitian ini, peneliti hanya meneliti hasil penilaian laboratorik yaitu pemeriksaan trombosit, kreatin, SGOT/AST. Hipotesis penelitian Severe Maternal Morbidity lebih banyak di jumpai pada ibu Preeklampsia yang hasil laboratorik tidak normal dibandingkan dengan ibu preeklampsia yang hasil laboratorik normal. Penelitian ini merupakan penelitian kohort retrospektif. Sampel dalam penelitian ini semua ibu preeklampsia periode 01 Januari 2014 sampai dengan 31 Desember 2017. Hasil pemeriksaan laboratorik tidak normal pada ibu preeklampsia dengan terjadiny severe maternal morbidity didapatkan nilai p value 0,000 dan OR 4,384 (95 persen CI: 2,053 - 9,361). Hal tersebut dapat diartikan bahwa ibu dengan hasil laboratorik tidak normal berisiko mengalami severe maternal morbidity 4,384 kali dibandingkan hasil lab normal. Simpulan hasil pemeriksaan laboratorik mempunyai hubungan signifikan dengan terjadinya severe maternal morbidity.

This is an open access article under the CC-BY-SA license. 


\section{PENDAHULUAN}

Morbiditas dan mortalitas pada preeklampsia masih sangat tinggi, untuk menurunkan angka morbiditas dan mortalitas maternal diperlukan upaya sungguh-sungguh menurunkan insiden penyakit dengan usaha pencegahan, penanganan dini dan manajemen terapi yang tepat. Amerika Serikat angka morbiditas dan mortalitas meningkat secara signifikan, morbiditas maternal berat terjadi 50-100 kali lebih sering dari pada kematian (Main et al., 2016). Morbiditas maternal rawat inap meningkat, selama persalinan dan merupakan faktor risiko kematian ibu. Adapun komplikasi yang menentukan morbiditas maternal berat seperti gagal ginjal akut, syok, edema paru, transfusi darah, histerektomi, rupture uterus dan eklampsia.

Preeklampsia tetap menjadi penyebab utama kematian ibu dan perinatal yang merupakan penyakit khusus pada kehamilan yang ditandai dengan hipertensi, proteinuria (Steegers et al., 2010). Menurut Organisasi Kesehatan Dunia (WHO) preeklampsia adalah gangguan heterogen yang mempengaruhi beberapa sistem organ. Risiko yang merugikan ibu dan perinatal meningkatkan secara signifikan ketika preeklampsia berkembang lebih awal, sebelum usia kehamilan 33 minggu atau setiap kehamilan pada ibu yang sudah mempunyai riwayat hipertensi ( $\mathrm{Su}$, Zhang and Wang., 2017., Chrisanto, E. Y., Rachmawati, M., \& Yulendasari, R. 2020). Secara keseluruhan, $10 \%$ sampai $15 \%$ kematian maternal disebabkan preeklampsia/ eklampsia (Kristianingsih, A., Mukhlis, H., \& Ermawati, E. 2019).

Negara berkembang eklampsia sering terjadi di perkirakan 16-69 kasus per 10.000 kelahiran hidup dibandingkan dinegara maju seperti di Eropa dengan 2-3 kasus per 10.000 kelahiran hidup (Duley.,2009). Di Amerika Latin dan Karibia hampir 26\% kematian ibu disebabkan oleh hipertensi sedangkan di Afrika dan Asia mereka berkontribusi sebanyak 9\% kematian ibu. Kejadian preeklampsia telah meningkat di Amerika Serikat disebabkan oleh peningkatan prevalensi gangguan predisposisi seperti hipertensi kronis, diabetes dan obesitas, rendahnya sosial ekonomi dapat meyebabkan terjadinya preeklampsia/ eklampsia. Preeklampsia merupakan penyebab utama morbiditas ibu (Steegers et al., 2010., Mukhlis, H., \& Marini, M. 2020).

Tujuan penelitian ini untuk mengetahui hubungan hasil pemeriksaan klinis dan laboratorik pada ibu preeklampsia dengan risiko terjadinya severe maternal morbidity di RSUD Panembahan Senopati Bantul. Adapun manfaatnya Hasil penelitian ini diharapkan dapat menjadi sumber informasi dan bahan referensi bagi tenaga kesehatan khususnya bidan mengenai severe maternal morbidity yang disebabkan oleh preeklampsia dan dapat memberikan asuhan kebidanan untuk mencegah terjadinya eklampsiadan HELLP syindrom dan meningkatkan kualitas pelayanan kebidanan khususnya pendamping kehamilan, persalinan, nifas yang komprehensif.

Penilaian laboratorik yang dapat memperkirakan risiko perkembangan preeklampsia pada ibu hamil menjadi HELLP syndrome dengan melakukan pemeriksaan jumlah sel darah dan pengukuran trombosit, setelah mendapatkan hasil laboratorik melihat apakah ibu tersebut masuk kelas 1,2 atau 3. Untuk tes Laboratorik Laktat Dehidrogenase (LDH), Aspartat Aminom Transferase (AST) dan asam urat digunakan untuk menilai keparahan penyakit tujuan mempermudah dokter memprediksi perjalanan penyakit yang didasarkan pada informasi diagnosis. Kriteria diagnosis HELLP Syndrome ditegakkan.

Hasil pemeriksaan laboratorium Trombosit $<100.000 / \mathrm{mm} 3$, AST> $72 \mathrm{U} / \mathrm{L}, \mathrm{LDH} 600 \mathrm{U} / \mathrm{L}$ (Araujo et al., 2006). Sedangkan Martin (1999) hanya mengelompokkan
HELLP Syndrome berdasarkan jumlah trombosit, disebut kelasi 1 jika jumlah trombosit $\leq 50.000 / \mathrm{mm} 3$, kelas II jika jumlah trombosit $>50.000 / \mathrm{mm} 3-\leq 100.000 / \mathrm{mm} 3$, dan kelas III jika trombosit $>100.000 \mathrm{~mm} 3-\leq 150.000 / \mathrm{mm} 3$.

Upaya menurunkan angka kematian ibu pemerintah memiliki beberapa kebijakan yaitu melakukan program JKN (Jaminan Kesehatan Nasional), ANC terpadu, meningkatkan akses dan kualitas pelayanan kesehatan ibu dan reproduksi, melaksanakan kelas ibu hamil, melakukan orientasi program perencanaan persalinan dan pencegahan komplikasi (P4K), meningkatkan kunjungan neonatal pertama (KN1), ibu hamil harus mendapat pelayanan antenatal minimal 4 kali (K4) dan menyelenggarakan kegiatan kesehatan remaja (Dinkes., 2016)

WHO (World Health Organization) sekitar 15\% dari seluruh kehamilan akan berkembang menjadi komplikasi yang berkaitan dengan kehamilan seperti perdarahan, infeksi, eklampsia, partus lama dan komplikasi abortus. Antenatal Care (ANC) merupakan salah satu upaya pencegahan awal dari komplikasi kehamilan. ANC dapat dideteksi secara dini komplikasi kehamilan sehingga mengurangi severe maternal morbidity. Sebanyak 84\% ANC dilakukan oleh bidan dan $14 \%$ dilakukan oleh tenaga medis lainnya. Adapun peran bidan dalam penanggulangan masalah pada ibu hamil, bersalin dan nifas terhadap kasus preeklampsia dengan melakukan perawatan antenatal yang tepat dengan memperlihatkan hasil pemeriksaan laboratorik lengkap dan melakukan rujukan awal ke pusat regional dengan keahlian dan memberi edukasi kepada ibu hamil, bersalin dan nifas tanda-tanda peringatan yang terkait dengan preeklampsia yang bisa membahayakan ibu dan perinatal supaya bisa menurunkan angka morbiditas di Indonesia (Maesaroh, S., Mukhlis, H., \& Widyastuti, F. 2019)

Tiga kelainan yang sering terjadi pada ibu hamil dengan preeklampsia yaitu kelainan laboratorium hemolisis intravaskuler, peningkatan kadar enzim-enzim hepar dan jumlah trombosit yang rendah (Syafrullah et al., 2016). Dari permasalahan yang telah diuraikan diatas, penulis tertarik untuk melakukan penelitian tentang "Hubungan hasil pemeriksaan laboratorik pada ibu preeklampsia dengan risiko terjadinya severe maternal morbidity di RSUD Panembahan Senopati Bantul"

\section{METODE}

Sampel dalam penelitian ini semua ibu preeklampsia periode 01 Januari 2014 sampai dengan 31 Desember 2017. Populasi 389 kasus, yang memenuhi kriteria inklusi 191 kasus dibagi dalam 2 kelompok yaitu kelompok dengan faktor risiko hasil laboratorik tidak normal 101 kasus dan hasil lab normal 90 kasus. Penelitian ini merupakan penelitian kohort retrospektif. Teknik pengambilan sampel consecutive sampling. Dianalisis menggunakan statistik risiko relatif dan regresi logistik. Penelitiaan ini dilakukan di RSUD Panambahan Senopati Bantul data yang digunakan adalah penelusuran catatan rekam medik hasil lab di RSUD Panambahan Senopati Bantul.

\section{HASIL DAN PEMBAHASAN}

Hasil analisis bivariat pemeriksaan laboratorik tidak normal berisiko mengalami severe maternal morbidity 1,295 kali (CI 95\% 1,056 - 1,588). Dibandingkan ibu dengan hasil lab normal. Hasil menunjukkan bermakna secara statistik. Secara teoritis kejang disebabkan oleh disfungsi endotel seluruh organ tubuh termasuk otak dan adanya kelainan laboratorik dilihat dari nilai trombosit, peningkatan kadar 
SGOT dan kadar SGPT sehingga menyebabkan morbiditas pada ibu. Menurut penelitian Hawa, 2009., Mukhlis, H. Nurhayati, N., \& Wandini, R, 2018) menjelaskan bahwa faktor risiko terhadap mortalitas ibu didapatkan hasil pemeriksaan laboratorik (Angka trombosit, SGOT dan SGPT) yang bermakna secara statistik. Menurut penelitian Suwoto (2017) menjelaskan bahwa trombosit, LDH, SGOT/SGPT merupakan faktor prognosis yang mempengaruhi terhadap kejadian eklampsia. Hasil kadar trombosit kecil dari $140.000 / \mu \mathrm{L}$ berisiko mengalami severe maternal morbidity 1,484 kali (CI 95\% 1,343 - 1,640) dibandingkan ibu dengan kadar trombosit besar dari $140.000 / \mu \mathrm{L}$. Hasilnya tidak bermakna secara statistik tetapi mempunyai risiko 1,4 kali terjadinya severe maternal morbidity.

Penelitian Van Dam et al (1989) bahwa preeklampsia trombositopenia berhubungan dengan tingginya morbiditas dan mortalitas pada ibu maupun bayi. Penelitia Schiffatal (1996) menjelaskan bahwa ibu hamil preterm dengan preeklampsia berat segera diterminasi apabila di dapatkan salah satu hasil kadar trombosit kurang dari $100.000 \mu \mathrm{L}$ untuk menurunkan insidensi morbiditas dan mortalitas maternal. Dan menurut penelitian Martin bila didapatkan kadar trombosit dibawah $150.000 / \mu \mathrm{L}$ segera mengakhiri kehamilan, agar morbiditas dan mortalitas ibu dapat diturunkan. Menurut penelitian Muzayanah (2001)dalam studinya menyatakan bahwa trombosit dibawah nilai ambang batas akan meningkatkan risiko pasien preeklampsia-eklampsia kematian ibu. Adanya hemolisis, peningkatan kadar enzim hepar dan penurunan jumlah trombosit merupakan gejala preeklampsia berat, eklampsia dan Hellp Syndrome (Martin JN etal.,1999., Handayani, F., \& Kameliawati, F. 2020).

Hasil Analisis bivariat kadar kreatin kecil dari 0,6 mg/ dL dan besar dari1.10mg/dL berisiko mengalami severe maternal morbidity 1,217 kali (CI 95\%1,001-1,480) dibandingkan ibu dengan kadar kreatin tidak berisiko jika besar $0.60 \mathrm{mg} / \mathrm{dL}$ sampai $1.10 \mathrm{mg} / \mathrm{dL}$. Hasil menunjukkan bermakna secara statistik. Penelitian ini sama dengan penelitian Tiawarman (2011) dimana kreatinin serum $>1,2 \mathrm{mg} / \mathrm{dL}$ dengan nilai $\mathrm{p}=0,0001$ memiliki hubungan yang signifikan untuk kematian ibu dan berperan sebagai prediktor morbidity dan mortality dengan kekuatan prediksi 17,0\%.Karakteristik ibu dengan SGOT besar sama dari 31 berisiko mengalami severe maternal morbidity 1,416 kali (CI 95\% 1,192 - 1,682) dibandingkan ibu dengan SGOT kecil dari 31. Hasil menunjukkan bermakna secara statistik (Kristianingsih, A., Mukhlis, H., \& Ermawati, E. 2019).

Hasil bivariat kombinasi hasil lab dengan severe maternal morbidity diperoleh hasil bahwa kreatin tidak normal berisiko mengalami severe materna morbidity dibandingkan trombosit dan kreatinin tidak normal, Kreatin

dan SGOT tidak normal, trombosit tidak normal maupun SGOT tidak normal bermakna secara statistik. Sama dengan penelitian Sedangkan trombosit dan kreatinin tidak normal, Kreatin dan SGOT tidak normal, trombosit tidak normal maupun SGOT tidak normal tidak bermakna secara statistik sebab sampel yang terlalu kecil.

Hasil bivariat, variabel luar dengan kejadian severe maternal morbidity diperoleh hasil bahwa ibu dengan usia kecil dari 20 tahun atau besar dari 35 tahun lebih banyak mengalami severe maternal morbidity dibandingkan ibu dengan usia 20-35 tahun dengan nilai $\mathrm{p}=0,659$ dan RR 1.076 (CI 95\% 0,882 - 1312) menunjukkan tidak bermakna secara statistik.

Hasil ini sangat mungkin terjadi sebab ini merupakan gambaran yang menggembirakan akan ke berhasilan para tenaga kesehatan khususnya Bidan dalam memberi konseling kepada remaja supaya tidak melakukan pernikahan dini sehingga berkurangnya kehamilan pada usia sangat muda kecil dari 20 tahun dan pada usia relatif tua besar dari 35 tahun. Penelitian ini sama dengan penelitian Yuliawati, (2001)., Xanda, A. N., Safitri, O., \& Panduwinata, R. (2019) kelompok usia ibu kecil dari 20 tahun atau besar dari 35 tahun mempunyai risiko terjadinya preeklampsia dibandingkan kelompok usia 21-35 tahun, ini secara statistik tidak bermakna (Mukhlis, H., dkk. 2020).

Hasil analisis bivariabel ibu dengan paritas anak pertama atau lebih dari tiga berisiko mengalami severe maternal morbidity sebesar 1,289 kali (CI 95\% 1,000 - 1,661) di bandingkan paritas 2 sampai 3 anak. Hal tersebut dapat dijelaskan dari penelitian Malmstrom (2014) bahwa Hellp Syndrome pada kehamilan kedua jarang terjadi, tetapi risiko relatif sangat tinggi pada wanita dengan Hellp Syndrome pada kehamilan pertama, sehingga menyebabkan morbiditas berat pada ibu preeklampsia. Hasil analisa bivariat ibu dengan kehamilan ganda mengalami severe maternal morbidity 1,302 kali (CI 95\% 0,983 - 1,724) Nilai $\mathrm{p}=0,663$ dibandingakan dengan kehamilan tunggal. menunjukkan hasil tidak bermakna secara statistik. Penelitian ini sama dengan penelitian Rozikhan (2008) bahwa tidak ada perbedaan yang signifikan antara kehamilan ganda dengan terjadinya preeklampsia berat. Ibu dengan jenis persalinan seksio sesarea lebih banyak mengalami severe maternal morbidity di bandingkan jenis persalinan pervaginam dengannilai $\mathrm{p}=0,027$ dan $\mathrm{RR} 1,245$ (CI 95\% 1,026 - 1,510) hal ini bearti bahwa bermakna secara statistik. Sesuai dengan penelitian Siswishanto (2002) dan Wardani, dkk, (2019) persalinan seksio sesarea secara statistik bermakna meningkatkan lama perawatan ibu setelah melahirkan dan meningkatkan kejadian morbiditas demam ibu dibandingkan persalinan secara vaginal.

Tabel 1

Hubungan hasil laboratorik, paritas dan jenis persalinan terhadap severe maternal morbidity

\begin{tabular}{|c|c|c|c|c|c|}
\hline & & $\mathrm{P}$ & OR & $\mathrm{Cl}$ & $95 \%$ \\
\hline Hasil Lab & $\begin{array}{l}\text { Tidak normal } \\
\text { Normal }\end{array}$ & 0.000 & 4.384 & 2.053 & 9,361 \\
\hline Jenis persalinan & $\begin{array}{l}\text { Seksio Sesarea } \\
\text { Pervaginam }\end{array}$ & 0.007 & 2.657 & 1.310 & 5.389 \\
\hline Paritas & $\begin{array}{l}\text { Berisiko jika anak pertama atau }>3 \\
\text { Tidak beresiko jika anak } 2-3\end{array}$ & 0.001 & 3.779 & 1.769 & 8.074 \\
\hline
\end{tabular}

Hasil analisis multivariat variabel luar yang paling berpengaruh adalah jenis persalinan dan paritas. Pada kaitan dengan severe maternal morbidity adalah seksio sesarea dimana nilai $\mathrm{p}=0,007$ sejalan dengan penelitian Waterstone et al (2001) dimana seksio sesarea empat kali lipat risiko morbiditas. Adapun cara memprediksi dan mengurangi risiko morbiditas maternal berat yang diperlukan dengan penanganan perdarahan dan preeklampsia. Dan pada kasus paritas mempunyai angka signifikan yang bermakna yaitu $\mathrm{p}$ $=0,001$, sejalan dengan penelitian Rozikhan(2008). Hal ini 
tidak berbeda dengan teori yang mengatakan bahwa pada primigravida pembentukan antibodi penghambat (blocking antibodies) belum sempurna sehingga meningkatkan risiko terjadinya preeklampsia. Perkembangan preeklampsia semakin meningkat pada umur kehamilan pertama dan kehamilan dengan umur yang ekstrem, seperti terlalu muda atau terlalu tua (Manuaba., 2007).

The New England Journal of Medicine tercatat bahwa pada kehamilan pertama risiko terjadi preeklampsia 3,9\%, kehamilan Kedua 1,7\% dan kehamilan Ketiga1,8\% (Di kutip dalam Rozikhan., 2007). Analisis multivariat penelitian ini didapatkan hasil ada hubungan yang bermakna antara hasil pemeriksaan lab tidak normal dengan faktor risiko terjadinya severe maternal morbidity. Hal ini sesuai dengan temuan Sibai (2005) yang menyakatan HELLP syndrome memiliki hubungan dengan kejadian morbidity dan mortality, terutama ketika terjadi setelah melahirkan, namun demikian parameter laboratorik ALT besar dari $40 \mathrm{U} / \mathrm{L}$ dan trombosit kecil dari 150.000 / $\mu \mathrm{L}$ memiliki hubungan yang bermakna sebagai prediktor kejadian morbidity dan mortality ibu pada HELLP Syndrome. Dan sama dengan penelitian Suwoto (2017) dan Sukirno, R. S. H. (2019) yang menyatakan hasil pemeriksaan laboratorik (Trombosit, LDH, SGOT/SGPT)

\section{DAFTAR PUSTAKA}

Araujo, Ana., Leao, et all. (2006). Characteristics and treatment of hepatic rupture caused by HELLP syndrome.Am J Obstet Gynecol. Vol. 195, pp. 1-5. Retrieved from: https://doi.org/10.1016/jajog.2006.01.016.

Chrisanto, E. Y., Rachmawati, M., \& Yulendasari, R. (2020). Penyuluhan manfaat buah naga merah dalam menurunkan kadar gula darah pada penderita diabetes melitus. Indonesia Berdaya, 1(2), 89-94.

Dinas Kesehatan Bantul. (2016). Laporan Tahunan Direktorat kesehatan Keluarga 2016, Jakarta

Duley, L. (2009). The Global Impact of Pre-eclampsia and Eclampsia. Seminars in Perinatology, 33(3), 130-137. https://doi.org/https://doi.org/10.1053/j.semperi.2009.02.0 10

Handayani, F., \& Kameliawati, F. (2020). Pelatihan pijat oksitosin untuk meningkatkan produksi ASI pada ibu menyusui. Indonesia Berdaya, 1(1), 23-28.

Hawa., La Royba. (2009). Faktor risiko kematian maternal pada preeklampsia berat dan eklampsia di RS Sardjito Tahun 2004-2007. Tesis. Obstetri dan Ginekologi Fakultas Kedokteran. Yogyakarta: Universitas Gajah Mada.

Kristianingsih, A., Mukhlis, H., \& Ermawati, E. (2019). FaktorFaktor yang Berhubungan dengan Kejadian Perdarahan Post Partum di RSUD Pringsewu. Wellness And Healthy Magazine, 1(2), 139-149.

Maesaroh, S., Mukhlis, H., \& Widyastuti, F. (2019). Efektifitas Terapi Hand Tappyng Terhadap Kecemasan pada Perempuan yang Sedang Menjalani Persalinan. Wellness And Healthy Magazine, 1(1), 7-14.

Manuaba, Ida Bagus Gde. (2007). Pengantar Kuliah Obstetri. Jakarta : EGC. pp. 407 - 411. (2010). Imu Kebidanan, penyakit Kandungan dan Keluarga Berencana untuk Pendidikan Bidan. Jakarta: EGC.

Main, E. K., Abreo, A., McNulty, J., Gilbert, W., McNally, C., Poeltler, D., Lanner-Cusin, K., Fenton, D., Gipps, T., Melsop, K., Greene, N., Gould, J. B., \& Kilpatrick, S. (2016). Measuring severe maternal morbidity: validation of potential measures. American Journal of Obstetrics \& Gynecology, 214(5), 643.e1-643.e10. merupakan faktor prognosis yang mempengaruhi terjadinya eklampsia.

\section{KESIMPULAN DAN SARAN}

Hasil pemeriksaan laboratorik Trombosit, Kreatin dan SGOT) berhubungan secara bermakna dengan peningkatan kejadian severe maternal morbidity pada pasien ibu preeklampsia. Ibu dengan paritas anak pertama atau lebih dari tiga dan jenis persalinan seksio sesarea berhubungan bermakna

Saran untuk penelitian ini adalah untuk mendapatkan hubungan dari faktor risiko lain perlu dilakukan penelitian dengan jumlah populasi lebih banyak dan cakupan wilayah lebih luas. Pada saat pengambilan sampel power penelitian $80 \%$ setelah penelitian diperoleh power $\pm 73,5 \%$. Diharapkan peneliti selanjutnya dengan power $80 \%$ atau RR $1,5.74$. Saran untuk RS untuk meningkatkan kualitas pelayanan dipemeriksaan laboratorik diharapkan melakukan pemeriksaan lengkap dan pengisian rekam medis hendaknya lengkap selama perawatan pasien. Melakukan diagnosa dini dan intervensi yang tepat dapat mencegah komplikasi yang mengancam kehidupan dari gangguan preeklampsia.

Martin Jr., J. N., Rinehart, B. K., May, W. L., Magann, E. F., Terrone, D. A., \& Blake, P. G. (1999). The spectrum of severe preeclampsia: Comparative analysis by HELLP (hemolysis, elevated liver enzyme levels, and low platelet count) syndrome classification. American Journal of Obstetrics \& Gynecology, $\quad 180(6), \quad 1373-1384$. https://doi.org/10.1016/S0002-9378(99)70022-0

Martin Jr., J. N., May, W. L., Magann, E. F., Terrone, D. A., Rinehart, B. K., \& Blake, P. G. (1999). Early risk assessment of severe preeclampsia: Admission battery of symptoms and laboratory tests to predict likelihood of subsequent significant maternal morbidity. American Journal of Obstetrics \& Gynecology, 180(6), 1407-1414. https://doi.org/10.1016/S0002-9378(99)70026-8

Martin, J. N., Blake, P. G., Perry, K. G., McCaul, J. F., Hess, L. W., \& Martin, R. W. (1991). The natural history of HELLP syndrome: Patterns of disease progression and regression. American Journal of Obstetrics and Gynecology, 164(6, Part 1), https://doi.org/https://doi.org/10.1016/00029378(91)91429-Z

Malmstrom Ola., Morken., Nils Halv. (2014). Hellp Syndrome, risk faktors in First and second pregnancy: a populationbased cohort study. J Obstet Gynecol. Retrieved from: https://doi.org/10.1111/aogs.13322.

Mukhlis, H., \& Marini, M. (2020). Pengaruh terapi murottal terhadap denyut nadi dan pernafasan pada bayi dengan berat badan lahir rendah. Indonesia Berdaya, 1(1), 29-37.

Mukhlis, H., Nurhayati, N., \& Wandini, R. (2018). Effectiveness of jasmine oil (jasminum officinale) massage on reduction of labor pain among primigravida mothers. Malahayati International Journal of Nursing and Health Science, 1(2), 47-52.

Mukhlis, H., Putri, R. H., Puspita, L., Wardani, P. K., \& Fitri, N. L. (2020). Variables Associated To The Decline Of Cognitive Function In The Third Trimester Of Pregnancy. Journal of Critical Reviews, 7(14), 1449-1456.

Muzayyah. (2001). Penilaian hasil Laboratorik sebagai faktor prognosis Kematian maternal pada preeklampsia/ eklampsia: Angka trombosit, Aspartat dan Kreatin. Tesis. Fakultas Kedokteran. Yogyakarta: Universitas Gajah Mada. 
Rozikhan. (2008). Faktor-Faktor Risiko Terjadinya Pre-eklampsia Berat di Rumah Sakit Dr. H. Soewondo Kendal Tahun 2007. Tesis. Program Magister Epidemiologi Universitas Diponogoro, Semarang.

Schiff E. Friedman SA, Frangich AY, Sibai BM. (1996). Clinical Utility of Strict diagnostic criteria for the Hellp Syndrome. Am J Obstet Gynecol. 1996; 174. pp. 460-4.

Sibai, Baha M., Ramadan, Mohanned K., Usta, Ihab., Salamah, Mostafa., Mercer, Brian M., Friedman, Steven A. (1993). Maternal morbidity and mortality in 442 pregnancies with hemolysis, elevated liver enzymes, and low80 platelets (HELLP syndrome). Am J Obstet Gynecol. pp. 1000-1006. Retrieved from: https://doi10.1016/0002-9378(93)90043-I.

Baskett, T., \& Arulkumaran, S. (2011). Severe pre-eclampsia and eclampsia. In Intrapartum Care for the MRCOG and Beyond (Membership of the Royal College of Obstetricians and Gynaecologists and Beyond, pp. 251-260). Cambridge: Cambridge University Press. doi:10.1017/СBO9781139680790.025

Sibai, B., Dekker, G., \& Kupferminc, M. (2005). Pre-eclampsia. The Lancet, 365(9461), 785-799. https://doi.org/10.1016/S0140-6736(05)17987-2

Steegers, Eric AP., Dedelszen, Peter Van., Duvekot, Johannes J. Pijnenborg Robert. (2010). Pre-eclampsia. Seminar. Vol 376. Retrieved from : https://doi.org/10.1016/S01406736(10)60279-6

Sukirno, R. S. H. (2019). Kesabaran Ibu Merawat Bayi Berat Lahir Rendah (BBLR). Journal of Psychological Perspective, 1(1), $1-14$.

Su, Yuan Yuan., Zhang, Jin Zhi., Wang, Fang. (2017). Risk factors and adverse outcomes of preeclampsia: a tertiary care centre- based study in China. J Obstet Gynecol. Vol. 28, No. 3, pp. $1262-1265$

Suwoto Sugeng. (2017). Faktor prognosis kejadian eklampsia pada pasien preeklampsia di RSUD DR. Sardjito Yogyakarta tahun 2013-2015. Tesis.Yogyakarta bagian Obstetri dan Ginekologi Fakultas Kedokteran Universitas GadjahMada.

Syafrullah, S., Lisiswanti, R. (2016). Preeklamsia Berat dengan Parsial HELLP Sindrom Severe Preeklamisa with Partial HELLP Syndrome, 6.

Van Dam P, Martin R, Ramso R, Mazor M, Lockwood CJ. (1989). Clinical Significance Prevalence and Natural History of Trombocytopenia in preeclampsia. Am. J Perinatal. Vol. 6, pp. $32-8$

Wardani, P. K., Mukhlis, H., \& Pratami, R. (2019). Pengaruh Essensial Lemon Terhadap Emesis Gravidarum pada Ibu Trimester I di Kecamatan Natar Kabupaten Lampung Selatan. Wellness And Healthy Magazine, 1(2), 131-138.

Waterstone, M., Bewley, S. and Wolfe, C. (2001). Incidence and predictors of severe obstetric morbidity: case-control study, BMJ (Clinical research ed.), 322(7294). pp. 1089-934. Retrieved from https://doi.org/10.1097/0000625420020300000004

Xanda, A. N., Safitri, O., \& Panduwinata, R. (2019). Psikoedukasi kesehatan dalam melakukan perawatan payudara pada ibu nifas. Journal of Psychological Perspective, 1(2), 67-72. 